\title{
Therapeutic and prophylactic aspects of colorectal cancer in the work of a family doctor in general practice
}

\author{
Summary \\ were discussed. The ways of early detection of the disease were offered. \\ Key words: colorectal cancer, sigmoidoscopy, early detection, screening test.
}

The article adduces the possible reasons of the colorectal cancer. The methods of treatment and prevention

Colorectal cancer is the most commonly diagnosed, noncutaneous cancer in Australia. In 2004 there were 12.973 cases of colorectal cancer (7.157 in men and 5.816 in women) and 4.077 deaths (2.189 in men and 1.888 in women) were registered. In Australia, the lifetime risk of developing colorectal cancer by the age of 85 years is approximately one among 10 men and one among14 women.

Colorectal cancer is less common in people under the age of 50 years, with the median age at diagnosis being 70. As it is shown in the box below, risk increases with age.

\begin{tabular}{|c|c|c|}
\hline $\begin{array}{c}\text { Risk - related to age } \\
\text { (for both sexes) }\end{array}$ & $\begin{array}{c}\text { Risk in the next } \\
\mathbf{5} \text { years }\end{array}$ & $\begin{array}{c}\text { Persons age next } \\
\mathbf{1 0} \text { years }\end{array}$ \\
\hline 30 years & 1 in 7000 & 1 in 2000 \\
\hline 40 years & 1 in 1200 & 1 in 400 \\
\hline 50 years & 1 in 300 & 1 in 100 \\
\hline 60 years & 1 in 100 & 1 in 50 \\
\hline 70 years & 1 in 65 & 1 in 30 \\
\hline 80 years & 1 in 50 & 1 in 25 \\
\hline
\end{tabular}

Risk is also greater for people with a family history of the disease. About two per cent of patients with colorectal cancer suffer from genetic syndromes associated with an exceptionally high risk of colorectal cancer and another 15 to 20 per cent have a family history of colorectal cancer without an identified genetic predisposition (see categories 1 to 3 below).

\section{Prevention}

Factors receiving the most attention as predisposing to a higher incidence of colorectal cancer are:

- Energy

- Dietary Factors

- Nutritional Supplements

- Other Agents: Aspirin, Non-steroidal, anti-inflammatory agents
- Physical activity

- Smoking

Studies in the prevention of colorectal malignancy include a number of different disciplines such as, cell biology, human nutrition, epidemiology, molecular genetics and animal models.

The proportion of colorectal malignancy attributed to nutritional factors has been estimated to be about $50 \%$. A recent review of diet and cancer estimates that $66-75 \%$ of malignancy of the colon and rectum can be prevented by diet and physical activity.

\section{Energy Intake}

There is a consistent positive association with energy intake and the risk of colorectal cancer. The evidence is sufficient enough to recommend reducing energy intake, both to prevent colorectal cancer and also for other reasons.

Recommendation

Restricting the energy intake in most males to less than 2500 kilocalories (10.480kj) per day and in most females to less than 2000 kilocalories (8360kj) per day helps to prevent carcinoma or adenoma (a benign tumor arising from the glandular epithelium in the colon.) Most colon cancers arise in pre-existing adenoma formation.

\section{Dietary Fat}

The incidence of colorectal cancer and adenoma formation is high with a larger fat intake (more than $40 \%$ of the total calorie intake). Increase dietary fat has shown to increase the hepatic synthesis of cholesterol and bile acids, and their increase presence in the colon and feces. Bacteria flora can convert these sterols into cholesterol metabolites and oxidized bile acids, which have a tumor promoting activity in animal models. The Toronto polyp study showed no benefit, though the results were not differentiated by adenoma size. The Australian polyp study demonstrated a marginally statistically significant result for low fat diets (less than $25 \%$ of the calories as fat) after two and four years of intervention on the occurrence of adenomas of $1 \mathrm{~cm}$ in size. Results show that 
since there has been no change in the weight of participants the carcinogenic potential is due to dietary fat rather than associated energy. A notable exception in the relationship of fat to colorectal carcinoma is omega-3 fatty acids (fish and fish oils), which reduce epithelial cell proliferation. Further trials are in progress on the effects of fat and development of malignancy.

\section{Recommendation}

Dietary fat should be less than $25 \%$ of the calorie intake.

\section{Meat}

Whilst the majority of studies on the effect of meat showed a positive association between red meat and colorectal carcinoma, this association however is weak and in only two studies was the trend towards increasing the risk statistically significant. The American institute of Cancer research attributed increases in risk, more to red meat than to fat. The Australian Polyp study fat reduction was achieved by design without reduction in red meat. It was concluded that inhibition of polyp growth was due to fat reduction rather than red meat consumption. High temperature cooking (barbecuing) of red meat causes the formation of heterocyclic amines, which are subsequently metabolized to form carcinogens. The evidence however is inconsistent that increased intake of heavily browned meat or high values of heterocyclic amines produced as a result of cooking meat, increases the risk of colorectal cancer.

\section{Fiber}

Cellulose or fiber is a major component of plant cell walls. On a global scale, it is estimated that plants produce one hundred billion tones of cellulose per year. Cellulose is a polymer of glucose. Each glucose molecule in cellulose is in the beta configuration, making every other glucose molecule up side down with respect to the others. Cellulose macromolecules are s traight and are never branched. Humans do not produce the enzymes necessary to digest cellulose. The fibers pass through the digestive tract and are eliminated with the feces. Some bacteria can digest cellulose, breaking it down to glucose monomers. Parallel cellulose molecules are held together by hydrogen bonds. About eighty molecules of cellulose are associated together to form a microfibril the main architectural unit. In 8 of 10 controlled studies the risk of polyp formation was decreased with higher consumption of plant food. The mechanism of action is not clear but it may act by decreasing the concentration of carcinogens or by reducing the transit time and thus the exposure time to the carcinogens. Carcinogens are thought to induce carcinoma in two stages, initiation and promotion. Initiation results from exposure of the mucosa cells to an appropriate dose of the carcinogen causing permanent DNA damage, and is therefore irreversible and has "memory». Promoters can induce cancer in initiated cells, but they are not tumorigenic by themselves. Tumors do not result when the promoting agent is applied before the initiating agent. Another possible mechanism is through the formation of bacterial fermentation products - short chain fatty acids. There appears to be a better protection from vegetables than cereals. Vegetable intake seems to be particularly important especially such as Brussels sprouts, broccoli, cabbage, cauliflower, mustard greens and turnips. The active compo- nents of these vegetables have not as yet been identified however scientific pursuit is at full flower.

\section{Recommendation}

Eat 5 or more portions a day of a variety of vegetables and fruit.

Cereal fiber varies in its solubility. Poorly soluble fiber such as wheat bran, continue to be fermented in the intestines, producing short chain fatty acids, which decrease the luminal $\mathrm{pH}$, inhibiting bacterial enzymes capable of carcinogen production. A number of studies have shown greater protection from insoluble than soluble cereal fiber.

\section{Recommendation}

Select poorly soluble cereal fibers (Wheat bran)

In contrast to the data for vegetable fiber, evidence for a protective affect by fruits is more limited and inconsistent both for colorectal carcinomas and adenomas.

\section{Micronutrients}

Recent studies show no significant effect of calcium and vitamin D on the development of colorectal cancer and no general recommendation can be made at present regarding carcinoma prevention. In contrast to calcium and vitamin $D$, folate studies suggest a beneficial effect. Low folate diets are a risk for adenoma and carcinoma especially in habitual alcohol consumers. Low folate diets enhance the development of chemically induced cancers in rodents.

Recommendations

Vegetable diet high in folate (wheat bran, bakers yeast, spinach)

\section{Phytonutrients}

Nutrients in plants (vegetables, fruits and cereals) have anticancer properties independent of their fiber content. Vegetables of importance include cabbage, cauliflower, broccoli, Brussels sprouts, garlic, onion, chives, tomatoes as well as fruits containing vitamin C, E and carotenoids. The evidence at present is only epidemiological, however it underlines the need for a high vegetable and fruit intake.

\section{Alcohol}

Total alcohol intake rather than specific types of alcohol is more consistently associated with increased risk of colorectal cancer.

Mechanisms that could be involved include enzyme induction of procarcinogens, inhibition of DNA repair and concurrent nutritional deficiency. The effect of alcohol appears to be stronger in men than women. Australian studies have found the association to be particularly prominent in beer drinking by men. Wine is less implicated and rectal carcinoma does not seem to be related to wine drinking.

\section{Nutritional Supplements}

A good general principle is to encourage eating whole foods rather than promoting nutritional supplements, as it is more likely that whole foods will contain more anticancer agents than those 
identified so far. Calcium and folate supplements are unlikely to be useful on the current evidence available. It has been shown that in animals calcium binds to fatty acids and therefore protects the colonic epithelium from their toxic effects. Randomized double blind, placebo control studies in humans did not show any significant effect on the proliferation of rectal mucosa. As for folate, although supplementation has a protective effect in rats, no human studies have been performed so far. The story with selenium however is more promising. This is an essential trace element in humans. The main effect is to reduce oxidative damage to the DNA. Deficiency may occur in diets lacking whole grain and vegetables, and from foods derived from soils with low selenium concentration. Populations deficient in selenium have an increased incidence of, and mortality from colorectal carcinoma. Studies provide evidence that supplementation with selenium has a protective effect against colorectal cancer. Despite the current evidence further information with appropriately designed trials is necessary before recommendations regarding selenium supplementation should be made.

Antioxidants such as vitamin $A$ and $C$ are not advised at the present to protect against colorectal carcinoma. Randomized controlled studies of vitamin A, C, E and beta-carotene have been negative. A Canadian trial of vitamin A and $E$, an Australian study of beta-carotene and a further study with vitamin $C$ and $E$ has showed no significant benefits.

\section{Other Chemoprevention agents}

Other candidates for chemoprevention of colorectal carcinoma include aspirin and non-steroidal anti-inflammatory agents. The Melbourne colorectal study showed that regular aspirin use was associated with a $40 \%$ lower risk of colorectal cancer. Further case controlled studies have shown significant reduction of the relative risk for those taking non-steroidal anti-inflammatory agents on a regular basis. It has been suggested that the effect was achieved because the drugs lead to bleeding which thus lead to earlier diagnosis. This suggestion was settled in a case control studied in the United States where those taking aspirin for medical reasons were compared with those taking other anticoagulants. Although all had and increase risk of bleeding only the aspirin group had a decrease risk of colon cancer. Studies in Sweden and Finland showed that patients with rheumatoid arthritis show a reduced incidence of colorectal cancer. The likelihood of developing colorectal cancer is $30 \%-40 \%$ lower in these patients as compared to the general population. In the Nurse's health study, five hundred and fifty one thousand female nurses taking aspirin were followed for eight years. Those who were regular users of aspirin over a ten to twenty year period showed a reduction in the relative risk to 56 . The most significant prospective study of aspirin use and cancer was preformed by the American cancer society. Aspirin intake by more than 662000 adults in the United States was documented and then followed for seven years; the death rate from colorectal cancer was noted. A dose-response relationship was noted. For those who took 16 or more aspirins per month for at least ten years, the relative risk of fatal colon carcinoma was 36. For those taking aspirin 16 or more times a month for at least a year. the relative risk was 60 for males and 58 for females. The current pool provides evidence of reduction in the risk of colorectal cancer from regular use of aspirin or NSAID but, the results are not consistent and there is lack of information regarding dosage, duration, age of recommended onset and options regarding different NSAID. The balance between toxicity and benefit has to be clearly evaluated. Of additional interest was the finding that other gastrointestinal cancers were also reduced.

\section{Recommendation}

Aspirin and NSAID chemoprevention is consistently protective in case of control studies but is not recommended until dosage and balance between risk and benefit is evaluated in randomized controlled trials.

\section{Physical Activity}

The evidence that physical activity protects against colon cancer as distinct from rectal cancer is strong and convincing. The data for rectal cancer is not consistent. The majority of studies show protection. The exact mechanism is not clear although stimulation of transit times, and immune or hormone mechanisms have been postulated. The data for carcinoma of the rectum is not consistent.

Recommendation

Be physically active to protect against colon cancer.

\section{Smoking}

The majority of studies show an increased risk from smoking of at least $50 \%$. A number of results are statistically significant. The evidence is stronger for rectal rather colonic carcinoma. The risk is also higher in those patients that have been smoking for longer periods of time. The results are even more consistent with adenomas.

\section{Recommendation}

Avoid Smoking

Appropriate dietary measures; together with physical activity and maintaining a healthy weight and avoiding smoking and alcohol could in time substantially reduce the incidence of colorectal cancer.

Long-term adherence to healthy lifestyle and dietary recommendations may lower the risk of colorectal cancer at the population level, although the degree of risk reduction is yet to be quantified.

\section{Healthy lifestyle}

It is suggested that all people participate in moderate to vigorous physical activity for 30 to 60 minutes per day, maintain a healthy body weight, avoid or limit alcohol consumption (no more than two standard drinks per day for men and no more than one standard drink per day for women) and do not smoke. Current smokers should quit smoking.

\section{Early detection}

colorectal cancer satisfies all nine of the WHO principles of screening. Randomized controlled trials (RCTs) have provided the highest level of evidence to show that population screening for 
bowel cancer using faecal occult blood testing (FOBT) is effective in reducing mortality from the disease. A number of case-control studies have indicated that screening with flexible sigmoidoscopy could also reduce mortality. However, definitive results from three RCTs currently in progress will not be available for several more years. There is no RCT evidence to support population screening based on colonoscopy.

\section{Faecal occult blood testing}

The FOBT-based RCTs used chemical (guaiac tests), which were affected by diet and medication and required samples from three bowel actions. Laboratory-based immunochemical tests, specific for human haemoglobin, are now available. These tests have greater acceptability as they are not affected by diet or medication and most only require samples from two bowel actions.

\section{General enquiries about screening}

If you have an enquiry about screening from an asymptomatic patient who is concerned about prevention, their level of risk, or the possible presence of colorectal cancer, the following process is recommended:

Take a thorough history focusing on risk factors, namely;

- Age;

- Symptoms (see symptoms of colorectal cancer below);

- Family medical history (age of onset, number of affected family members, and which side of the family);

- Individual history of colorectal adenomas, colorectal cancer, inflammatory bowel disease;

\section{Quantifying risk based on family history}

Individuals can be placed in one of three categories of relative risk, based on their family history.

\section{Category 1 - those at or slightly above average risk}

This covers about 98 per cent of the population.

People fit into this category if there is:

- No personal history of colorectal cancer, colorectal adenomas or chronic inflammatory bowel disease and no confirmed close family history of colorectal cancer;

- One first-degree (parent, sibling, child) or second-degree (aunt, uncle, niece, nephew, grandparent, grandchild) relative with colorectal cancer diagnosed at age 55 or older; Two relatives diagnosed with bowel cancer at age 55 or older but on different sides of the family.

\section{Screening guidelines:}

FOBT is recommended at least every two years for all people over the age of 50 . Full examination of the large bowel, preferably by colonoscopy, is recommended in those shown to have a positive FOBT. If eligible, participation in the national bowel cancer screening program should be recommended. For those not eligible for the national program, advice on access to FOBT is available from.

Consider sigmoidoscopy (preferably flexible) every five years from the age of 50 .

It is important that GPs advise individuals to re-present if they develop symptoms of colorectal cancer. In symptomatic patients, particularly those aged over 40 years or those with a personal his- tory of colorectal adenomas, referral to a specialist should be considered. Full examination of the large bowel with colonoscopy is recommended.

\section{Category 2 - those at moderately increased risk}

This covers one to two per cent of the population.

People fit into this category if there is:

One first-degree relative with colorectal cancer diagnosed before the age of 55 (without potentially high risk features as in category 3); or two first or one first and one second-degree relative/s on the same side of the family with colorectal cancer diagnosed at any age (without potentially high risk features as in category).

\section{Screening guidelines:}

Offer colonoscopy every five years starting at 50 , or at the age of 10 years younger than the age of first diagnosis of colorectal cancer in the family, whichever comes first.

Flexible sigmoidoscopy plus double-contrast barium enema or CT colonography may be offered if colonoscopy is contraindicated for some reason.

Consider offering FOBT in the intervening years. Patients should be informed that a positive test will require further investigation.

\section{Category 3 - those at potentially high risk}

This covers less than one per cent of the population.

- People fit into this category if there are:

- Three or more first-degree relatives or a combination of first and second-degree relatives on the same side of the family diagnosed with colorectal cancer; or

- Two or more first or second-degree relatives on the same side of the family diagnosed with colorectal cancer plus any of the following high-risk features:

- Multiple colorectal cancers in a family member;

- Colorectal cancer before the age of 50 years;

- An hereditary non-polyposis colorectal cancer (HNPCC)related cancer (endometrial, ovarian, stomach, small bowel, renal pelvis or ureter, biliary tract, brain cancer); or

- At least one first-degree or second-degree relative with a large number of adenomas throughout the large bowel (suspected familial adenomatous polyposis (FAP)); or

- Member of a family in which a gene mutation that confers a high risk of bowel cancer has been identified.

\section{Screening guidelines:}

Consider referral to a familial cancer service for further risk assessment and possible genetic testing.

Refer to a bowel cancer specialist to plan appropriate surveillance and management. This may include:

FAP: Flexible sigmoidoscopy yearly or second-yearly, starting from age 12-15 years until polyposis develops, then prophylactic surgery. If family genetic testing is inconclusive and no polyposis develops, sigmoidoscopy reduced to every 3 years after the age of 35 , then change to population screening if examinations normal to age 55. Prophylactic surgery, e.g. restorative proctocolectomy, is appropriate for those with proven FAP.

HNPCC: Colonoscopy every one to two years from age 25 , or five years earlier than the youngest diagnosis in the family (whichever comes first). FOBT may be offered in alternate years or to 
subjects unwilling to accept colonoscopy. There are options for surveillance at other sites, usually starting from age 25-35. Prophylactic surgery may be appropriate for some.

\section{Symptoms of colorectal cancer}

The most common presenting symptoms of colorectal cancer are:

- bleeding from the rectum, mixed with or separate from the faeces;

- a change in bowel habit, especially a recent one;

- symptoms of anaemia;

- abdominal pain, especially if of recent onset;

- weight loss.

These symptoms are not always clear-cut and can have a variety of other causes, including more common conditions such as haemorrhoids.

\section{Investigation of symptoms}

Investigation must be tailored to the circumstances.

The recent onset of symptoms in a patient over 40 years of age raises the index of suspicion for colorectal cancer, and investigation is important in this situation. Referral to a specialist should be considered.

Persons under 40 years of age should be investigated if there is a positive family history, if there is not an identified cause of symptoms, or if symptoms are persistent.

When a decision is made to investigate, it is appropriate to perform a thorough examination of the anus, rectum and colon by one or more of the following in order to make a definitive diagnosis:

- Digital rectal examination and sigmoidoscopy; and

- Colonoscopy; or

- Air contrast barium enema and sigmoidoscopy; or

- CT colonography.

The accuracy and safety of these investigations depends upon quality issues. Only colonoscopists who are appropriately credentialed should be consulted. If investigations are incomplete, an alternative investigation is necessary.

\section{Adenomatous polyps}

If any polyps are seen at colonoscopy they should be removed.

For patients with adenomatous polyps:

- Repeat colonoscopy is warranted if there is uncertainty about completeness of removal of an adenoma. The colonoscopist should be able to clear the colon of polyps.

- Surveillance colonoscopy should be performed at three years for a large adenoma (more than $1 \mathrm{~cm}$ in diameter), adenomas with high-grade dysplasia or villous change, multiple (3 or more) adenomas, or those aged 60 or more with a firstdegree relative with colorectal neoplasia.

Surveillance colonoscopy may be delayed to four to six years for single tubular adenomas less than $1 \mathrm{~cm}$ in diameter.

\section{Adjuvant therapies Colon cancer}

Those with resected node-positive colon cancer (stage C (III)), unless having significant co-morbidity, should be routinely offered adjuvant chemotherapy.

For those with Stage B (II) colon cancer, a decision regarding adjuvant treatment should be made following a discussion of merits and side effects of chemotherapy. High-risk sub-groups may benefit more from adjuvant chemotherapy.

\section{Rectal cancer}

Adjuvant chemotherapy and radiotherapy should be offered to patients if they have non-metastatic, low to mid-rectal cancer that has either penetrated the rectal wall and/or involved local lymph nodes, because it significantly improves survival and local tumour control.

Preoperative therapy is preferred to postoperative therapy as it may lower the incidence of morbidity and is associated with a lower rate of local recurrence.

Postoperative chemotherapy and radiotherapy is recommended for patients with high-risk rectal cancer who did not receive preoperative therapy, because it improves survival and local tumor control.

\section{Communication with the patient}

Information should be provided to patients in a form and manner that helps patients understand the problem and treatment options available, and which is appropriate to the patient's circumstances, personality, expectations, fears, beliefs, values and cultural background.

\section{Patient information}

Where possible, the following information should be provided in collaboration with the GP, surgeon and stoma therapy nurse to a patient with colorectal cancer:

- The causes of colorectal cancer and the extent of the disease;

- Proposed approach to investigation and treatment, including information on expected benefits, the process involved, common side effects, whether the intervention is standard or experimental, who will undertake the intervention, and the likely consequence of choosing a particular treatment, or no treatment;

- The time and costs involved;

- Emotional reactions, appearance after surgery, and the effect of cancer and its therapy on interpersonal and sexual relationships;

- Genetic implications for close relatives;

- Access to special items (stoma devices) and entitlements to benefits and services (travel subsidies and prostheses);

- Access to cancer information services.

\section{Quality of life}

Doctors involved in the management of patients with colorectal cancer should be aware of the potential impact of treatment on quality of life and should include this in decision making.

Patients should be informed of the likely impact of treatment alternatives on their quality of life.

\section{Support}

Support needs for patients with colorectal cancer and their families may include:

- Psychosocial support and counselling, including sexuality and fertility;

- Access to a cancer support service and/or an ostomy support group; 
- Education and assistance with stoma therapy;

- Assistance with care of children or other family members;

- Assistance with transport, travel and accommodation;

- Dietary advice.

\section{Screening tests}

Screening doesn't stop bowel cancer occurring, so it's important to be aware of the symptoms that could indicate bowel cancer and what you can do to reduce your risk.

Symptoms to look out for include:

- Change in bowel habit i.e. a recent onset of diarrhea or constipation. Bleeding from the back passage or blood mixed in the stool. Abdominal pain that persists. A low blood count or anaemia.

- bleeding from your bottom and/or blood in your poo

- a change in your bowel habit lasting three weeks or more

- unexplained weight loss

These include: regular exercise, maintaining ideal weight and eating a diet low in fat and high in fibre. Known factors that will increase your risk are:close relative with bowel cancer (parents, children or siblings)

- Bowel polyps (abnormal growth of cells on the bowel wall that form a mushroom-like lump)

- Inflammatory bowel diseases such as Ulcerative Colitis and Crohn's disease.

Genetic conditions where there are multiple polyps (e.g. Familial Adenomatous Polyposis - FAP)

\section{Colorectal cancer management}

\section{Clinical trials}

Doctors should encourage patients with colorectal cancer to consider participating in appropriate clinical trials for which they are eligible.

\section{Preoperative assessment}

Routine preoperative assessment includes a full medical history and physical examination, with particular interest in cardiorespiratory assessment.

All patients who have a reasonable chance of a post-operative stoma should be prepared for this possibility. The patient should be seen by an experienced stoma therapist before surgery.

\section{Preparation for surgery}

Many patients having surgical resection of the colon still have a bowel prep, although there is no evidence that this reduces infection rates or morbidity following surgery. Therefore, mechanical bowel preparation is not routinely indicated unless there are anticipated problems with faecal loading that might create technical difficulties with the procedure.

Patients undergoing surgery should receive prophylaxis for thromboembolic disease.

Prophylactic antibiotics are required in colorectal surgery. A single preoperative dose of intravenous cephalosporin and metronidazole or gentamicin and metronidazole is an effective regimen.

\section{Elective surgery for colon cancer}

An en bloc resection of the primary colonic cancer together with the appropriate lymph nodes is undertaken.
In experienced hands, laparoscopic surgery has an equivalent short-term outcome to conventional surgery.

\section{Rectal cancer}

In general, sphincter saving operations are preferred to abdominal perineal resection. With the use of modern instruments and surgical specialization, most rectal tumours can be removed with preservation of the sphincters to avoid the implications of a permanent colostomy.

Local excision of small rectal tumours can be effective in selected cases.

\section{Emergency surgery}

A large proportion of patients (about 20 per cent) with colorectal cancer will present as an emergency.

This may be because of obstruction, perforation or significant bleeding. Patients should be urgently sent to an appropriate hospital and usually require surgery with resection of the cancer and management of any complications.

\section{Tests}

If your doctor suspects you may have bowel cancer, internal examinations of the back passage and special tests will be organized. A referral to a specialist colorectal surgeon may be arranged. Your doctor or specialist may perform: a digital (finger) examination of the back passage.

An endoscopic examination of the back passage, rectum and colon with either a rigid sigmoidoscopy (up to $20 \mathrm{~cm}$ ), flexible sigmoidoscopy (up to $60 \mathrm{~cm}$ ) or colonoscopy (all of the large bowel). A sample of tissue may be sent for pathology during these internal examinations

- An X ray that outlines the colon (CT colonography). A scan of the abdomen i.e. CT scan.

- An internal ultrasound examination - endorectal ultrasound. A scan of the pelvis and rectum i.e. an MRI scan. After the results of these tests are available, your doctor or specialist would discuss a plan of management. It is best at this stage to be accompanied by a friend or relative to help you in understanding the explanation and treatment plan.

\section{Treatment}

\section{Follow-up after curative resection}

Intensive follow-up for colorectal cancer should be performed for patients who have had potentially curable disease.

\section{Local management}

Surgery, radiation therapy or chemotherapy may be offered to patients with locally advanced or recurrent disease.

Systemic chemotherapy significantly prolongs life when compared to best supportive care in patients with metastatic colorectal cancer.

The cure of liver and/or lung metastases is possible, providing all disease can be resected. This approach is supported by metaanalyses with long-term follow-up.

\section{Palliative care}

Palliative care management should be offered to all patients who experience intractable symptoms associated with advanced cancer. Valuable assistance can be obtained from consultation with palliative care specialists. This management may involve a wide range of therapies. 


\section{Psychosocial care}

Psychosocial care is important. Psychosocial interventions should be a component of care as they can improve the quality of life for patients with cancer. The National Breast and Ovarian Cancer Centre's Clinical practice guidelines for the psychosocial care of adults with cancer - A summary guide for health professionals has been developed to assist health professionals in providing evidence-based psychosocial care for adults with cancer and their families. The summary guide outlines key emotional issues to consider when treating patients with cancer and includes practical recommendations to promote adjustments and detect and treat emotional issues.

The most effective treatment, with the aim of cure, is surgical excision of the involved bowel. This means removing 20 to $40 \mathrm{~cm}$ of the bowel, though longer lengths of the bowel may be removed. Chemotherapy and/or radiotherapy may be given either before or after surgery. The aims of this treatment are to reduce: the size of the cancer, the chance

\section{Резюме}

\section{Лікувально-профілактичні аспекти колоректального раку в практиці сімейного лікаря}

\section{В. Сабалаш, О. Губська, О. Барна}

Національний медичний університет імені О.О. Богомольця, Київ

У статті висвітлено можливі причини виникнення раку товстої і прямої кишок. Були обговорені методи лікування та попередження захворювання. Запропоновано шляхи виявлення хвороби на ранніх стаАіях.

КАючові слова: рак товстої і прямої кишок, сигмоїАОскопія, рання Аіагностика, скринінговий тест of spread and the chance of the cancer recurring. When used to prevent the spread of cancer, it is called adjuvant treatment. When cancer has already spread and cannot be completely removed, it is used to relieve symptoms and is called palliative treatment.

If the patient has rectal cancer, he may require a permanent colostomy if the cancer is very close to the back passage. Developments in medical technology, especially surgical staplers and specialists training in colorectal surgery, have significantly reduced the need for a permanent colostomy. The vast majority of patients with bowel cancer will not need a colostomy. When modern techniques are used and the bowel is joined to the back passage, a temporary bag (loop ileostomy) may be necessary to reduce the complications of surgery. The temporary bag is usually closed at three to six months after surgery, depending on the need for adjuvant treatment.

Аодаткова інформація. Автори заявляють про віАсутність конфлікту інтересів.

\section{Резюме}

\section{Лечебно-профилактические аспекты колоректального рака в практике семейного врача}

В. Сабадаш, Е. Губская, О. Барна

Национальный меАицинский университет имени А.А. Богомольца, Киев

В статье освещены возможные причины возникновения рака толстой и прямой кишок. БЫли в ОбсужАении метоАЫ лечения и преАупрежАения заболевания . ПреАложены пути выявления болезни на ранних стаАиях.

КАючевые слова: рак толстой и прямой кишок, сигмоИАоскопия, ранняя АИагностика, скрининговый тест 